Social Sciences on Contemporary Turkey

\title{
Turkey and the European Union: The sociology of engaged actors and of their contribution to the candidacy issue
}

\section{Claire Visier}

\author{
(2) OpenEdition \\ Journals \\ Édition électronique \\ URL : http://journals.openedition.org/ejts/3910 \\ DOI : 10.4000/ejts.3910 \\ ISSN : 1773-0546 \\ Éditeur \\ EJTS
}

Référence électronique

Claire Visier, « Turkey and the European Union: The sociology of engaged actors and of their contribution to the candidacy issue », European Journal of Turkish Studies [En ligne], 9 | 2009, mis en ligne le 02 décembre 2009, consulté le 16 février 2020. URL : http://journals.openedition.org/ejts/3910 ; DOl : 10.4000/ejts.3910

Ce document a été généré automatiquement le 16 février 2020.

(c) Some rights reserved / Creative Commons license 


\title{
Turkey and the European Union: The sociology of engaged actors and of their contribution to the candidacy issue
}

\author{
Claire Visier
}

1 At the current time, more and more is being written about relations between Turkey and the European Union, with the heated debate surrounding Turkey's accession to the EU generating an abundance of articles and papers defending or condemning its candidacy. When considering the candidacy issue, scientific production mainly tends to use a description of the institutional history of the relationship between Turkey and the European Community as its starting point. Many works review the Turkish situation using legal, geopolitical, macro-economic and macro-political data, while other studies attempt to assess its candidacy from the perspective of the criteria defined by the EU, or the 'challenges' posed by its membership. The aim herein is not to take one side or the other in the debate about Turkey's accession to the EU, but rather to give an insight into the processes involved in the construction of the European issue using a sociological analysis of the actors involved. Considering that 'all social actors can help to define the European issue' (Pasquier \& Weisbein 2004: 13), we have chosen not to focus on the diplomatic actors involved in the ongoing negotiations, but to take into account other actors who are becoming directly or indirectly engaged on the issue of membership in Turkey, in European countries and the EU's capital cities (Brussels, Strasbourg, Luxembourg). This report sets out to confront a long-neglected perspective; that of the sociological and interactive aspect of the accession negotiations process. 


\section{Sociology of enlargement long-neglected by theoretical analyses.}

2 The impact of the extreme segmentation that exists between European studies and area studies has been the specialization of $a /$ analyses looking at enlargement (within European studies), and $b /$ studies on the internal dynamics of candidate countries. Proof of this can be seen in the significant lack of comparative studies on Central and Eastern European (CEE) countries and Turkey, and a little cross-knowledge of research pertaining to one geographical area or another (as shown by bibliographies).

Within European studies, theoretical approaches dedicated to EU enlargement have mainly been developed around three issues (Schimmelfennig \& Sedelmeier 2002: 504-507): the political action of candidate countries (why and under what conditions do non-members seek to join a regional organization?); the political action of Member States (under what conditions do Member States of a regional organization advocate or oppose the candidacy of a given country?); and lastly, the political action of the European Union (under what conditions does a regional organization accept new members or change its institutional relations with a third-party country?). In all cases, enlargement is constructed as a matter of foreign policy by candidate countries and by the European system. Analyses are marked by a conventional and realistic approach to international relations, whereby foreign policy is completely separate from and unconnected with domestic policy.

4 Theoretical analyses of EU enlargement have neglected the impact of the enlargement process on changes in the identities, interests and behaviour patterns of political and social actors. Furthermore, by focusing either on the European level, or on one or more candidate countries, they have also left the interactions and mutual influences that exist between these two levels in the shadows ${ }^{1}$, all the more so since they have tended to focus on the asymmetrical nature of relations between the EU and candidate country, and to highlight the coercive and hierarchical dimension of their relationship. This kind of approach has led to a mechanical and rational view of pre-accession, defined as 'a series of actions and reactions in which the Commission seems to be the sole instigator of policies. Thus, the European Union lays down the conditions for the candidate country, following which the latter starts doing the calculations and adjusting its response. The Union responds by giving out rewards or penalties' (Dakowska 2003: 106).

5 Area studies have not taken such theoretical analyses of enlargement on board. With regard to Central and Eastern European countries, the literature, of which there is much, has focused on their post-communist transformation and has rarely considered the impact of the European factor: 'when it comes to institutional reforms, economic policies and even political parties, [the literature] produced very few systematic analyses of the impact of pre-accession on political systems' (Neumayer 2003: 122). The enlargement process has given rise to plenty of highly empirical studies owing to the immediate and fast developing nature of the facts observed.

6 Up until the early 2000s, Turkish political scientists paid scant attention to European integration issues². M. Müftüler-Baç (2003) gives three main reasons for this lack of interest. Firstly, political science was strongly tied epistemologically and methodologically to philosophy and law and found it hard to integrate the empirical 
and evolutionary European construction process. Secondly, research in Turkey is centred primarily on domestic policy, political theory and the political role of Islam, and even political development, transition and democratic consolidation. Thirdly, attention has persistently focused on the economic nature of relations between the European Community and Turkey. Studies conducted in Turkey on the links between Turkey and Europe have mainly been confined to an overall interpretation of relations, putting the history of those relations back into the context of the geopolitical development of the international system and focusing on the strategic importance of Turkey to the European Community in the post-cold war international landscape (Balkir \& William 1993). Historical relations between Turkey and Europe have also been dealt with via the issue of Turkey's European identity and its relationship with westernization (Onïs 1999). Outside the confines of the Turkish scientific community, the main aspect singled out for attention by researchers is the geopolitical perspective, with special interest shown in such contentious matters as Cyprus, relations with Greece and regional equilibrium (Apostolou 1999; Ropper 1999; Park 2000; Suvarierol 2003).

7 Relations between Turkey and the European Community are thus considered in a relatively static manner. Above all, they are the product of and shaped by the international context. Certain analyses factor in the domestic variable, but only capture it from the point of view of an independent variable or structural datum influencing the definition of foreign policy.

\section{Complexification of the issue of Turkey-EU relations.}

8 From the end of the nineties, a number of studies were instrumental in making the issue of Turkey-EU relations more complex. They placed greater emphasis on the dynamic interactions firstly between foreign policy and domestic policy, and secondly between the action taken by Europe and Turkey's foreign policy, revealing differences of opinion between Turkey and the EC, and highlighting the contradictions in their relations.

B. Elmas (1998) examines the intentions and objectives of Turkish leaders since the Second World War, and underlines the 'obvious paradox' between a foreign policy geared towards European integration, and an anti-democratic domestic policy. M. Müftüler-Baç (1997) stresses Turkey's political context when referring, in addition to the Cypriot and Kurd issues, to the numerous shortcomings in the political system, all of them hurdles on the road towards integration. Nevertheless, in her opinion, there is an opportunity for change connected with the potential impact of the EU. Other authors remain more sceptical. B. Elmas shows that European policy has always lacked the determination to lead Turkey into integration. G. Dorronsoro (2003) mulls over Europe's inconsistencies; rather than being the result of a clear-cut and predefined process, the Turkish accession process is the ambiguous product of both economic interest and a diplomatic-cum-bureaucratic process. On the Turkish front, the desire to join the EU mainly springs from geopolitical and economic interests, not from any will to sign up to a European federation. Likewise, based on an analysis of the Customs Union in effect in 1996, D. Akagül (1999) puts into perspective two diverging ways of looking at integration: from the Turkish point of view, the Customs Union was one step 
further along the road to European integration, whereas the Europeans, not sharing this dynamic view, laid greater emphasis on notions of cooperation and partnership.

More than the post Cold War context, M. Önis (2003) and M. Ugur (1999) demonstrate the importance of the interactions between international influences and national forces, which lead to a virtuous or vicious circle from the European integration standpoint. M. Ugur turns his attention both to the effects of society/State interactions in the development and implementation of public policies in Turkey and to EC institutional dynamics. He sums up the specific tensions in Turkey-EU relations and the frequent failure to meet commitments through the notion of the 'anchor-credibility dilemma'. On the one hand, the European outlook of successive governments has never been credible because Turkey, given its political system, does not have the ability to adopt reforms. On the other hand, the EU has never played an effective role in 'anchoring' (effective anchor) Turkey in a genuinely EC outlook, as it has not produced enough incentives or sanctions to force it to adopt real change. As each of these two phenomena reinforces the other, a vicious circle is created. The Helsinki Summit decision in December 1999 broke this circle by partially reinforcing the anchoring of Turkey in Europe and thereby speeding up the pace of democratization in Turkey (Ugur 2003).

11 However, these studies remain highly state-centred. The impact of Europe is not analyzed as a process bringing into play different social actors who each express the European issue in their own way and according to their own potential. Ultimately the State is still a black box that hides more than it reveals, and the conflicts and negotiations between the different actors, and the trade-offs steering foreign policy are not analyzed.

\section{The revival in analyses of Turkey-EU relations}

12 The revival in analyses came about as a result of the gathering pace of events from 1999 onwards. The success of the concept of Europeanization and its move beyond the boundaries of European studies also enabled the issue of EU enlargement to be looked at in a new light.

13 With the acceptance of Turkey's candidacy for membership of the European Union at the Helsinki Summit in December 1999 and the victory of the AKP (moderate Islamist Justice and Development Party) in 2002, the hope that a date would be set for the start of negotiations restored a strong sense of keenness to the European issue and to the literature on the issue. A first package of major reforms was passed in August 2002 by the then three-party government coalition, consisting of the DSP (Democratic Left Party, centre left), the ANAP (Motherland Party, liberal centre right) and the MHP (National Movement Party, ultra-nationalist), despite bitter opposition from the MHP. The victory of the AKP in the November 2002 general election and the new face of parliament with just two parties, the majority AK Party and the CHP (Republican People's Party, centre left), then marked a turning point. Under the leadership of the new government and with the support of the parliamentary opposition, political reforms geared towards the opening of negotiations on EU membership were the main item on the country's political agenda. At the end of 2004, the European Union at last offered to start membership negotiations, albeit against a backdrop of growing debate and reservations about Turkey's candidacy in certain European countries. As a result of 
European procrastination on one side, and growing political tension in Turkey between the AKP, opposition parties and the military and judiciary establishment on the other, membership negotiations were pushed into the background in the years that followed.

14 The topicality of the Turkey-EU issue stirred up academic interest just as the concept of Europeanization was beginning to enjoy huge success. The aim herein is not to give a precise and unequivocal definition of Europeanization, used to describe a huge variety of phenomena and change processes (Olsen 2002). For our purposes, the concept is of interest in that it switches attention away from the construction of a supranational institutional order (the EU) and towards the transformations brought about at the domestic level by European construction. It reverses the perspective at the heart of international relations by stressing the impacts of international changes (the construction of a European order) on the domestic level, and sets out to examine the construction of Europe's political system by studying the mutual adjustment processes of the different actors and institutions moving forwards jointly in a changing environment. For example, it attempts to pinpoint and understand the convergence or divergence occurring between countries affected by European integration (Caporaso, Green Cowles and Risse 2001). As regards candidate countries, the concept looks at how EU membership is anticipated at the domestic level and how the constraints imposed and/or opportunities opened up by the negotiations process are internalized, as well as at the clashes between different internal actors and at the construction of the European issue at the domestic level. It puts the spotlight on 'the interactive dimension of the relationship between the EC system and actors in candidate countries, and also on the biases, tensions and even perverse impacts of this adaptation' (Dakoswka \& Neumayer 2004: 13).

In their introduction to a special issue of 'South European Society and Politics' on Turkey, Europeanization and Civil Society (2005), T. Diez, A. Agnantopoulos and A. Kaliber suggest that a distinction should be made between four different kinds of Europeanization: policy-Europeanization (the impact of European integration on policy making, including actors, policy problems, instruments, resources and styles - Radaelli 2000:3), political Europeanization (the impact of European integration on domestic institutional structures and political processes), societal Europeanization (a process of change in the 'construction of systems of meanings and collective understandings' within the context of European integration - Cowles \& Risse 2001: 219-), and discursive Europeanization (to what extent public claims make reference to the $\mathrm{EU}$, specific European actors or policies, and how this has changed over time).

From the early 2000s onwards, without necessarily using the Europeanization 'toolbox' or even referring to the concept, a certain number of works were published that fell in line with its meaning. The publication edited by A. Carkoglu and B. Rubin (2003), reverses the usual perspective adopted in the study of relations between Turkey and the EU, by examining Turkey's application for EU membership not only as a matter for foreign policy, but also as a crucial domestic policy issue. Certain contributions tackle the impact of the EU on domestic immigration and human rights policies; others analyze public opinion towards the EU and the attitudes of political and parliamentary parties, and even examine the roots of euro-scepticism. The perception of relations between Turkey and Europe coincides with other analyses looking at the attitudes of different social groups - Kurds (Bosarslan 2001), Islamists (Bozarslan 2001), the business community (Onis \& Türem 2002) and intellectuals (Monceau 2007) - towards 
the European project. These analyses provide a sort of snapshot of the stances taken by various actors on the European issue, but do not really bring to light the reasoning and logic at work in process of capturing and adjusting to the European issue.

The intention of the publication edited by M. Ugur and N. Canefe is to outline the 'international processes that have affected or are likely to affect the country's future in an integrated Europe' (2004: 8). This is an apparently rather loosely-defined perspective, since public policies, collective actors and representation structures are all considered at once. However, some of the contributions provide detailed insight into the processes at work in the reshaping of the political and social landscape around the European issue. For example, G. Avci examines changes in partisan politics in relation to the European issue using Ladrech's theoretical approach to the Europeanization of political parties (2001). Using C. Radaelli's definition (2001), S. Atan, describes in minute detail how interaction with EU level policy-making has in part shaped the negotiating patterns of Turkish business organizations and allowed them to intervene in the national policy reform process. The special issue of South European Society and Politics on Turkey, Europeanization and Civil Society already mentioned refers explicitly to the concept of Europeanization and sets out to highlight non-governmental actors:

'Given the existing literature on Europeanization, and the effect of the EU candidacy on Turkish civil society, there is a need to further explore how much the current constitutional and political change in Turkey is indeed driven by civil society actors, how it has changed the opportunities, but also the identities, aims and strategies of these actors, and whether these changes can be seen as part of a process of political and societal Europeanization' (2005: 10).

While it has its place in the issues raised by the concept of Europeanization, from the theoretical point of view, this issue of the EJTS does not fall completely in line with this perspective. The success of the concept of 'Europeanization' has gone hand in hand with the extension of its use. A number of the authors in this issue refer to it, but do not necessarily give it the same meaning. Having become an 'all-meaning concept', it seems increasingly difficult to use effectively, and some specialists agree that as things currently stand, Europeanization should be seen 'as a problem and not as a solution' (Radaelli 2004). The main criticism that might be directed against the concept is an excessive focus on the European factor at the risk of it actually being considered an independent variable. Such naturalization of the European factor causes people to pay little attention to the use made of it by actors and in the end, to see European integration as the ultimate cause of change.

\section{The sociology of engaged actors and of their contribution to the candidacy issue}

The aim of this EJTS report is to tackle the issue of Turkey's application for EU membership using a 'sociology of the European political space'. The term 'European political space' means the set of power relations exercised within a given institutional order (Lagroye 1997). This institutional order is the end product of the intertwining of internal and European orders which then are no longer considered as being separate or juxtaposed. The sociological approach invites us to 'study the individuals and organizations that make up this new political space and help to give it shape' (Guiraudon 2000). Far from passively submitting to Europe's orders and instructions, a host of social and political actors are engaged in and thus helping directly or indirectly 
to build Europe and define the European issue (Pasquier \& Weisbein 2004). It is important to understand how individual and collective actors anticipate (or do not anticipate), react to (or do not react to) and take on board (or do not take on board) the candidacy challenge. Together with this, the idea is also to highlight the interactive processes taking place. Instead of constructing the European issue separately from one another, through their many interactions, actors gain an awareness of one another and make Europe aware of their existence. Similarly, actors constantly move back and forth between different levels of action: European, national, local, sectorial, and institutional. By looking at the interactions between the individual level and the institutional level, the transformation mechanisms generated by the construction of a European political system can be brought to light.

The relationship with the EU is not merely the product of structural determinism highlighted by numerous macro-analyses. It is also being constructed dynamically through the appropriation, re-appropriation, investment in or withdrawal of involvement from the enlargement process by a large number of actors. The contributions to this issue stress the paths followed by actors and the socialization processes leading "to the things of Europe" (Georgakakis 2002; Michel \& Robert 2009). They shed light on the factors and actors involved in socialization: how can a stock of the knowledge and perceptions of the EU be accumulated? What role is played by socializing agents? How does European investment interfere with professional, partisan and ideological identities? The contributions attempt to give an update on how the way the situation is defined by actors is developing and how choices are made in the light of measures acquired during the previous phases of their journey. Using an anthropological analysis of Turkish interest groups in Brussels, B. Firat shows how these groups define Turkey's EU membership plans on the basis of their own daily interaction with non-Turkish European actors and with Turkish communities in Brussels. D. Yankay, in writing about the Islamic tendency MÜSIAD business organization, stresses the social learning process resulting from its members' exposure to European business practices and culture. She carefully highlights how this economic 'socialization' is linked to a pre-socialization stage marked by the religious reference, and gives rise to a new identity. Its process led to a creative adoption of European norms and their reinterpretation.

21 Studying actors and their journeys is also a way to pinpoint the social resources that influence engagement and the groups that own them. For example, O. Serdaroglu shows how the European issue was seized upon not by every single member of the TÜSIAD employers' organization, but by some of its most influential members who shared a common identity and identical resources. In the example of the movements against gold digging in the Aegean Sea, E. Öngün emphasizes the very special resources available to the actors who will play a key role in the move to Europe. The three articles looking at business organizations (TÜSIAD and MÜSIAD) and workers' unions clearly show how roles ${ }^{3}$ varying from the "pro-European" to the "anti-European" and including the many shades in-between, are emerging and/or changing.

By focusing on actors and their socialization, the authors are able to define precisely the uses made of Europe and to qualify certain theoretical models currently in fashion. 'Uses cover political practices and interactions that are being adjusted and redefined by seizing upon Europe as a set of wide-ranging opportunities (institutional, ideological, political or organizational). (...) Use implies deliberate action. (...) Whatever the nature 
of such opportunities (political, institutional, symbolic or financial, etc.), actors need to grasp them and turn them into practical policies' (Jacquot \& Woll 2004: 9-10). The literature on Europeanization (Caporaso, Cowles \& Risse 2001) and transnational relations (cf. the 'boomerang pattern', Keck \& Sikkink 1998) sees the use of Europe as a conscious strategy employed by actors with a view to wielding pressure, especially on their Government. In detailing the determinants of the use of Europe during the movements against gold digging, E. Öngün shows that the use of Europe was not necessarily intentional or strategic, but perhaps the result of more incidental processes. For her part, Z. Alemdar compares the use made of the European issue by various Turkish trade unions. She shows that the domestic environment in which these actors operate and likewise their ideological perception, more than mere union interests, are key to understanding their use of Europe.

This last comment introduces another aspect common to the different contributions: while analyzing the reasoning of actors and individuals as closely as possible, the authors also take into account the interactions that grow up between the actors themselves, and between the actors and the different institutions in which they intervene. Engaged actors occupy different positions in their original socio-political spaces and are involved in struggles for positions, thus structuring configurations at the national, European, international and transnational levels. Studying socio-political configurations and their lasting quality or possible reconstruction provides an understanding of the wide-ranging effects of Europe's emergence as a new horizon of meaning (Massicard 2001). D. Yankaya shows how the arrival in power in Turkey of the AKP (Justice and Development Party) is driving a change in the position of the religiously-oriented MÜSIAD business organization in the Turkish socio-political space, and influencing its new position on the European issue. Analyzing the politicization of the issue of Turkey's application for EU membership in France, C. Visier shows that the debate is not really indicative of France's relationship with Turkey but rather is part of the general French debate about European issues at the same time. Turkey is simply illustrative of some profound doubts about the EU.

Likewise, movements concerning the European issue may alter certain divides, redistribute political resources or enable new categories to emerge and thus drive changes in configurations. (Baisnée \& Pasquier 2007). F. Misrahi shows how the European dimension is likely to transform institutional arrangements between States and economic actors. A key finding of the literature on state-business relations in Turkey is that these relations suffer from a lack of cohesiveness of both sides of the relationship, and from a lack of institutionalization. This article, however, finds that relations between the state and a number of business sectors are highly institutionalized in the policy area of technical product regulations which is a policy highly impacted by the presence of a strong EU effect.

This EJTS issue doesn't come to any conclusions about the progress made or not made by Turkey's application for EU membership. It rather looks at many transformations and transformation mechanisms brought about by the European issue. 


\section{BIBLIOGRAPHIE}

Akagül, Deniz (1999) 'La Turquie et l'économie européenne : vers l'intégration ou la coopération ?', in Insel, Ahmet (eds.) La Turquie et l'Europe, une coopération tumultueuse, Paris, L’Harmattan, pp. 79-99.

Apostolou, Andrew (1999) ‘Turkey, the European Union, and Cyprus', Mediterranean Quarterly, (10) 4, pp.120-121.

Avci, Gamze (2004) 'Turkish political parties and the EU discourse in the post-Helsinki period: A Case of Europeanization', in Ugur, Mehmet; Canefe, Nergis (eds.) (2004) Turkey and European Integration. Accession Prospects and Issues, London, Routledge, pp. 194-214.

Atan, Serap (2004) 'Europeanisation of Turkey peak Business organisations and Turkey-Eu relations', in Ugur, Mehmet; Canefe, Nergis (eds.) (2004) Turkey and European Integration. Accession Prospects and Issues, London, Routledge, pp. 100-121.

Balkir, Canan; William, Allan M.(eds.) (1993) Turkey and Europe, London, Pinter.

Balme, Richard; Chabanet, Didier; Wright, Vincent (dir.), (2002), L'action collective en Europe, Paris, Presses de Sciences-Po.

Baisnée, Olivier ; Pasquier, Romain (2007) L'Europe telle qu'elle se fait. Européanisation et sociétés nationales, Paris, CNRS éditions.

Bozarslan, Hamit (2001) 'La candidature de la Turquie à l'UE : enjeux politiques internes et immigration', Politique étrangère, 66 (2), pp. 371-384.

Carkoglu, Ali; Rubin Bary (eds) (2003) Turkey and the European Union, Domestic Politics, Economic Integration and International Dynamics, London, Frank Cass.

Caporaso, James; Cowles, Maria Green; Risse, Thomas (2001) (eds.) Transforming Europe: Europeanization and Domestic Change, Ithaca, Cornell University Press.

Cowles, Maria Green; Risse, Thomas (2001) ‘Transforming Europe: conclusion’ in Caporaso, James; Cowles, Maria Green; Risse, Thomas (eds.), Transforming Europe: Europeanization and Domestic Change, Ithaca, Cornell University Press, pp. 217-238.

Dakowska, Dorota (2003) 'Usages et mésusages du concept de gouvernance appliqué à l'élargissement de l'Union européenne', Politique européenne, 10, pp. 99-120.

Dakowska, Dorota; Neumayer Laure (2004) ‘Pour une approche sociologique de l'élargissement : les acteurs européens dans les nouveaux Etats membres de l'UE', Contribution à la journée d'étude du groupe ‘Europe' de l'AFSP, « L'élargissement de l'Union : un premier bilan », IEP bordeaux, 4 juin. www.afsp.msh-paris.fr/activite/ groupe/europe/neumayerjuin2004.pdf

Dakowska, Dorota; Neumayer, Laure (eds.) (2005) ‘L’Union européenne élargie, acteurs et processus', Politique européenne, 15.

Dorronsoro, Gilles (2003) ‘The EU and Turkey, between geopolitics and social engineering', in Dannreuther, Roland (ed.) The UE and its Periphery, London, Routledge.

Diez, Thomas; Agnantopoulos, Apostolos; Kaliber, Alper (2005) ‘Turkey, Europeanization and Civil Society: Introduction', South European Society and Politics, (10) 1, pp. 1-15.

Jacquot, Sophie; Woll, Cornelia (2004) (eds.) Les usages de l'Europe. Acteurs et transformations européennes, Paris, l'Harmattan. 
Elmas, Hasan Basri (1998) Turquie-Europe : une relation ambiguë, Paris, Syllepse.

Georgakakis, Didier (2002) Les métiers de l'Europe politique. Acteurs et professionnalisations de la construction européenne, Strasbourg, Presses Universitaires de Strasbourg.

Guiraudon, Virginie (2000) 'L'espace sociopolitique européen, un champ encore en friche', Cultures et Conflits, 38-39, pp. 7-37.

Keck, Margaret; Sikkink, Katheryn (1998) Activists Beyond Borders. Advocacy Networks in International Politics, Ithaca, Cornell University.

Ladrech, Robert (2001) 'Europeanisation and Political Parties: Toward a Framework for Analysis', Queen's Papers on Europeanisation, 2, www.qub.ac.uk/ies/onlinepapers/poe2-01.pdf.

Lagroye, Jacques (1997) Sociologie politique, Paris, Presses FNSP-Dalloz.

Massicard, Elise (2004) ‘Politique pénitentiaire et contrainte externe. Autour de la réforme des prisons en Turquie', in Artières, Philippe; Lascoumes, Pierre (eds.) Gouverner, enfermer. La prison, un modèle indépassable?, Paris, Presses de Sciences-Po, pp. 157-175.

Michel, Hélène (2002) 'Le droit comme registre d'européisation d'un groupe d'intérêt. La défense des propriétaires et la Charte des droits fondamentaux de l'Union européenne', Politique européenne, 7.

Michel, Hélène; Robert Cécile (2009) 'L’Europe, enjeu, objet et agent de socialisation', colloque organisé par TRIANGLE (CNRS/ENS-LSH, Université Lyon 2, IEP de Lyon) et CERAPS (CNRS/ Université Lille 2), 9 -10/10/2009. Ouvrage à paraître.

Monceau, Nicolas (2007) Générations Démocrates, les élites turques et le pouvoir, Paris, DallozSirey.

Müftüler-Baç, Meltem (1997) Turkey's Relations with a Changing Europe, Manchester, Manchester University Press.

Müftüler-Baç Meltem (2003) ‘Turkish political science and European Integration', Jounal of European Public Policy, (10) 4, pp. 655-663.

Neumayer, Laure (2003) 'L'européanisation indirecte des pays candidats à l'adhésion à l'UE : le cas des politiques publiques de concurrence en Pologne et en République Tchèque', Politique européenne, 10, pp. 121-147.

Offerlé, Michel (1998) Sociologie des groupes d'intérêt, Paris, Montchrétien.

Olsen, Johan P. (2002), ‘The Many Faces of Europeanization', Journal of Commun Market Sudies, 4(5), dec., pp. 921-952.

Onïs, Ziya (1999) 'Turkey, Europe, and Paradoxes of Identity: Perspectives on the International Context of Democratization', Mediterranean Quarterly 10(3), pp. 107-136.

Önis, Ziya; Türem Umut (2002) 'Entrepreneurs democracy and citizenship in Turkey', Comparative Politics, (35) 4, pp. 439-456.

Onïs, Ziya (2003) 'Domestic politics, transantional influences and the impetus for reform: the deverse paths of Poland and Turkey on the road to EU membership', Koç University,URL: http:// home.ku.edu.tr/ zonis.

Park, William (2000) 'Turkey’s European Union candidacy: from Luxembourg to Helsinki- to ankara?', Mediterranean Politics, (5) 3, pp. 31-53. 
Pasquier, Romain; Weisbein, Julien (2004) 'L'Europe au microscope du local. Manifeste pour une sociologie politique de l'intégration communautaire', Politique européenne, 12, pp. 5-21.

Politique européenne (2005), 'L'UE élargie. Acteurs et processus', dossier thématique, 15.

Polo, Jean-François; Visier, Claire (2005) 'Les groupes d'intérêts turcs auprès des institutions européennes : une intégration bruxelloise', Pôle Sud, « La Turquie face à l’Europe », 23, pp. 9-24.

Polo, Jean-François; Visier, Claire (2007) 'De l'intégration à l'européanisation, les groupes d'intérêt turcs à Bruxelles', in Baisnée, Olivier ; Pasquier, Romain (2007) L'Europe telle qu'elle se fait. Européanisation et sociétés nationales, Paris, CNRS éditions, pp. 77-98.

Pridham, Geoffrey (2000) The dynamics of democratization, a comparative approach, London, Continuum.

Radaelli, Claudio (2000) 'Whither Europeanization? Concept stretching and substantive change', European Integration Online Papers (EioP), (4) 8, URL: http://eiop.or.at/eiop/texte/2000-008a.htm.

Radelli, Claudio (2001) 'The domestic impact of European publi policy: notes on concepts, methods and the challenge of empirical research', Politique européenne, 5, pp. 107-142.

Radelli, Claudio (2004) 'Europeanisation: solution or problem?' European Integration Online Papers (EioP), (8) 16, URL: http://www.eiop.or.at/eiop/texte/2004-016a.htm.

Roper, John (1999) 'The West and Turkey: varing roles, common interests', The International spectator, (34)4, pp. 89-102.

Saurugger, Sabine; Grossman, Emiliano (2006) Les groupes d'intérêt, Action collective et stratégies de représentation, Paris, Armand Colin.

Schimmelfennig, Frank; Sedelmeier Ulrich (2002) ‘Theorizing EU enlargement: research focus, hypotheses, and the state of research', Journal of European Public Policy, (9)4, pp. 500-528.

Sedelmeier, Ulrich; Wallace, Helen (2000) 'Eastern enlargement: strategy or second thoughts?' in Wallace, Helen; Wallace, William, (eds.) Policy making in the European Union, Oxford University Press, Oxford, pp. 427-460.

Smith, Andy (2004), Le gouvernement de l'Union européenne, une sociologie politique, Paris, LGDJ.

Suvarierol, Semin (2003) ' The Cyprus Obstacle on Turkey’s road to Membership in the European Union' in Carkoglu, Ali; Rubin Bary (eds) (2003) Turkey and the European Union, Domestic Politics, Economic Integration and International Dynamics, London, Frank Cass, pp. 55-79.

Ugur, Mehmet (1999) The European Union and Turkey: An Anchor/Credibility Dilemma, England, Ashgate, Aldershot.

Ugur, Mehmet; Canefe, Nergis (eds.) (2004) Turkey and European Integration. Accession Prospects and Issues, London, Routledge.

\section{NOTES}

1. The points raised by U. Sedelmeir and H. Wallace (2000) according to which enlargement gives rise to potential instrumentalization and continuous interactions on the CEE side, and by G. Pridham (2000), in whose view the correlation between the enlargement process and domestic policy issues should not be overlooked, have for a long time been neglected.

2. For example, in Turkey there is just one specialist European studies publication, the Marmara Journal of European Studies. 
3. 'Role' is defined as a 'set of behaviours expected of a person occupying a position and which enable that position to exist, be consolidated and especially made sensitive to others' (Lagroye 1997: 6).

INDEX

Mots-clés : Europe, Turquie

Keywords : Europe, Turkey

\section{AUTEUR}

\section{CLAIRE VISIER}

Université Rennes 1, Centre de recherche sur l'Action Politique en Europe claire.visier@univ-rennes1.fr 